\title{
Seasonal Climate Prediction and Adaptation Using Indigenous Knowledge Systems in Agriculture Systems in Southern Africa: A Review
}

\author{
Obert Jiri $^{1,2}$, Paramu L. Mafongoya ${ }^{1}$, Chipo Mubaya ${ }^{1,3} \&$ Owen Mafongoya $^{1}$ \\ 1 School of Agricultural, Earth and Environmental Sciences, University of KwaZulu-Natal, Scottsville, \\ Pietermaritzburg, South Africa \\ ${ }^{2}$ University of Zimbabwe, Faculty of Agriculture, Mt Pleasant, Harare, Zimbabwe \\ ${ }^{3}$ Chinhoyi University of Technology, Chinhoyi, Zimbabwe \\ Correspondence: Obert Jiri, School of Agricultural, Earth and Environmental Sciences, University of \\ KwaZulu-Natal, Private Bag X01, Scottsville, Pietermaritzburg 3209, South Africa. E-mail: \\ obertjiri@yahoo.co.uk
}

Received: February 17, 2016 Accepted: March 26, 2016 Online Published: April 15, 2016

doi:10.5539/jas.v8n5p156 URL: http://dx.doi.org/10.5539/jas.v8n5p156

\begin{abstract}
Erratic rainfall and increasing temperature is rapidly emerging as one of the most serious global problems affecting many sectors in the world. It is considered to be one of the most serious threats to sustainable development with adverse impact on environment, human health, food security, economic activities, natural resources and physical infrastructure. Southern Africa is one of the most vulnerable regions to climate change in the world, particularly because of widespread poverty, recurrent droughts, inequitable land distribution, over-dependence on rain-fed agriculture and low adaptive capacity. Yet rural farmers in southern Africa have managed to survive the vagaries of climate change over the years. This review reveals that these rural farmers can use indigenous knowledge to cope and adapt to climate change. Availability and access to scientific weather information to make cropping and other decisions at the local level remain key issues to usage of climatic data by rural farmers. On the other hand, indigenous knowledge is what rural farmers have been using but is also becoming unreliable due to climate change and variability. Integration of indigenous knowledge and scientific seasonal forecast seems to be a key possible thrust to reduce vulnerability, enhance resilience of rural farmers and increase their adaptive capacity.
\end{abstract}

Keywords: climate change, indigenous knowledge, seasonal weather prediction, adaptation

\section{Introduction}

Climate change exerts multiple stresses on the biophysical as well as the social and institutional environments that underpin agricultural production (IPCC, 2007). Khanal (2009) classified the patterns of impact of climate change on agriculture into biophysical and socio-economic impacts. Mark et al. (2008) highlighted some of the direct impacts of climate change on agricultural systems as: (a) seasonal changes in rainfall and temperature, which could impact agro-climatic conditions, altering growing seasons, planting and harvesting calendars, water availability, pest, weed and disease populations; (b) alteration in evapotranspiration, photosynthesis and biomass production; and (c) alteration in land suitability for agricultural production.

An important feature of drylands is the low seasonal rainfall amounts and the high rainfall variability (Khanal, 2009). High rainfall variability as manifested in variable onsets and rainfall amounts, dry spells, recurrent droughts and floods are intrinsic characteristics of many sub Saharan Africa (SSA) regions (Ifejika, 2010). This implies that rain-fed agriculture already has to account for these various characteristics. Yet, the widespread impacts of droughts and floods often force national governments to declare a state of emergency and appeal for external aid (WFP, 2006), indicating that smallholders are yet to meet the challenge of crop and livestock production under such climatic conditions.

Ifejika (2010) indicated that, at the level of practices, there are several ways to adapt to climate change at the farm-level. These different ways are mainly complementary as they address different components of the 
smallholder farming system. Adaptation is a continuum of practices which range from activities that are predominantly developmental to those that focus on reducing climate change impacts. No one single measure is sufficient to adapt to climate change. Rather, a mix of measures is needed which targets the various farm variables - water, soil, micro-climate, seeds and crops as well as labour and capital.

Most smallholder crops are highly sensitive to climate and ecosystems will shift over space in response to climate change. For instance, research done in various countries in southern Africa has demonstrated that a $2{ }^{\circ} \mathrm{C}$ rise in ambient temperature and a rise of mean temperature by $4{ }^{\circ} \mathrm{C}$ would significantly lower crop yields (Agoumi, 2003). Potential effects of climate change on maize, a staple crop, using a general circulation model and the dynamic crop growth model CERES-maize in Zimbabwe, showed that maize production was expected to significantly decrease by approximately $11-17 \%$, under conditions of both irrigation and non-irrigation (Agoumi, 2003; Magadza, 1994; Makadho, 1996; Mano \& Nhemachena, 2006; Muchena, 1994; Stige et al., 2006).

This sensitivity of agriculture in southern Africa, obtained through exposure to climatic hazards and stresses, could lead to increased vulnerability in the absence of adequate coping, adaptation and policy mechanisms, underpinned by access and use of climate information (Figure 1). How smallholder farmers respond to climate change and variability depends on the information they obtain and use to decipher appropriate coping and adaptation strategies (Gukurume, 2014). Such information can be derived from indigenous knowledge systems (IKS) or meteorological weather data or both. On the other hand, reduced vulnerability, encompassed by access and effective utilisation of climate weather forecast data, is shown by improved livelihoods and increased resilience to climate change (Figure 1).

This review covers research that has been done in Africa, particularly southern Africa, and examines the importance of climate forecasts, challenges that have been faced in southern Africa through scientific forecasts, the role played by indigenous forecasting and challenges that indigenous knowledge faces in development interventions, including opportunities in integrating scientific and indigenous forecasts. This paper is solely based on in-depth literature review of studies that have been done on Sub-Saharan Africa, with particular focus on southern Africa, regarding climate change adaptation and indigenous and scientific forecasting.

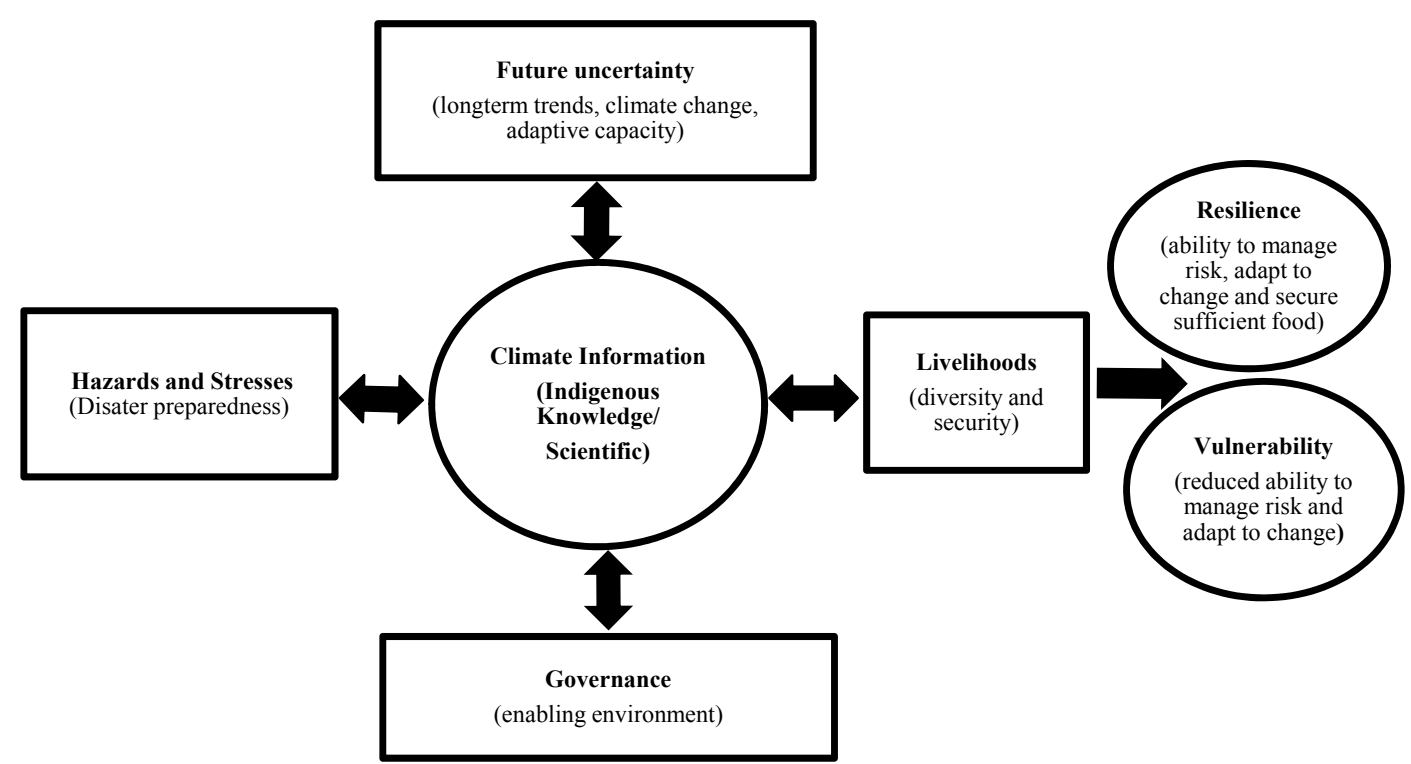

Figure 1. Framework of vulnerability and resilience based on access and usage of climatic information (modified from Pasteur, 2011)

Sustainable smallholder agricultural production cannot be achieved in the absence of local coping and adaptation capacity to current variability and change and adaptive capacities for future climate changes (Finnigan, 2009; Ogallo, 2010). Failure to adapt to climate change may lead to adverse impacts on major food crops at the farm level and in the region (Lobell et al., 2008). Climate information (including observations, research, predictions and projections) has a central role to play in both adaptation and mitigation of climate change (Zillman, 2009). In SSA, however, there is limited access to climate information and relatively low capacity to meaningfully utilize 
the provided information that farmers have access to (Dutta, 2009; Odendo et al., 2006). Farmers, therefore, tend to rely on indigenous knowledge and information from local social networks to make decisions and manage technology related risks and climate variability (Nyong et al., 2007; Pawluk et al., 1992).

The concept of indigenous knowledge has increasingly become topical and been embraced by academics and development practitioners as integral to addressing multiple livelihood challenges faced by rural communities in developing countries and as a basis for locally driven adaptation strategies that transcend the planning stage and can begin to be implemented (Mapfumo et al., 2015; Moonga \& Chitambo, 2010; Saitabau, 2014). More recent studies have shown that resilience building for smallholder farmers in Africa is a process that starts with the ability to anticipate change and accordingly adjust farming practices and set the base for sound food security, particularly in the context of climate variability and change (Kolawole et al., 2014).

\section{Sources of Seasonal Climate Forecast Information}

There is an inevitable demand for seasonal and medium- to long-term climate forecasts to support farmers in decision making. Farmers tend to use a combination of meteorological information and indigenous knowledge in their seasonal forecasting, as they primarily rely on indigenous knowledge but are also open to receiving scientific forecasts (Mapfumo et al., 2015; Orlove et al., 2010; Roudier et al., 2014). While smallholder farmers approach a season with a wealth of prior experience in empirical observation and traditional knowledge regarding forecasts, these farmers also adjust their practices as they seek further local information and also as scientific real-time forecasts become available (Furman et al., 2011; Frimpong, 2013; Orlove et al., 2010). It becomes difficult in some cases to ascertain which source of information influences what decision in the same season.It may, therefore, be prudent to assert that it is a combination of the types of forecasts that influences farmers' decision making. The trajectory of change highlights how farmers in a study conducted in West Africa more than a decade ago entirely relied on their experience and intuition to make decisions on their farms in a given season (Hansen, 2002) to currently where they make use of a combination of indigenous and modern forecasts in parts of southern Africa (Mapfumo et al., 2015).

Climate information appears to be particularly important and in many cases a prerequisite for coping and adapting to the negative impacts of climate variability and change, given that most of the rural livelihoods in southern Africa depend on climate and environmental dynamics (Goddard et al., 2010). What is emerging from a number of studies is that farmers tend to make decisions on farming practices based on potential evidence of climate occurrences, particularly in relation to rainfall patterns (Goddard et al., 2010; Mapfumo et al., 2015; Roudier et al., 2014). Studies further highlight that farmer crop management strategies (planting time, weeding, fertilizing, application of pesticides) are shaped by predictive climate information, particularly rainfall related forecasts (Moeletsi et al., 2013; Roudier et al., 2014). Environmental observables tend to guide farmers actions, among them soil moisture and expected weather conditions (Goddard et al., 2010; Moeletsi et al., 2013). Decision making is not restricted to modifications of these decisions but also by reinforcing what a farmer has already decided on, thereby having a psychosocial effect through encouragement to maintain good practices (Roncoli et al., 2009). Farmers have the capacity to use climate forecasts to maximize benefits from anticipated favourable conditions and governments in Africa have increasingly invested in climate services to enhance farmers' adaptive capacity (Roudier et al., 2014). However, farmers may not plan for an average season but for a poor season to ensure survival. Failure to plan for a good season but only for a poor one makes farmers miss out on profits in a good year (Goddard et al., 2010).

Studies show that climate information is instrumental in improving agricultural production and ultimately dealing with food insecurity (Friesland \& Lo"pmeier, 2006; Moeletsi et al., 2013; Patt et al., 2005; Phillips et al., 2001; Roncoli et al., 2009). There is an increasing realization that agroclimatological information, particularly that which provides details on climate extremes and recommendations for actions to be taken, is crucial to improve on agricultural production and responsible use of agricultural resources and managing agricultural risk (Figure 1; Friesland \& Lo"pmeier, 2006; Moeletsi et al., 2013). Agricultural productivity can be increased and costs of production minimized through informed use of weather/climate information, which makes it very important to ensure wide dissemination of this information (Balaghi et al., 2010; Basco, undated cited in Moeletsi et al., 2013). However, some scholars hasten to throw caution on over generalisation of the importance of climate change based on these studies given the small-scale nature of the sample size and exclusion of other important categories of society such as gender, among other factors (Roudier at al., 2014).

\section{Problems of Scientific Forecasts}

Climate information has increasingly become important and available in the last decade and Regional Climate Outlook Forums have enhanced dialogue on seasonal forecasts among producers of information, researchers and 
different categories of decision-makers (Goddard et al., 2010). Moreover, studies demonstrate that there is potential value in incorporating seasonal forecasts into the decision-making of different sectors (Cabrera et al., 2007; Hammer et al., 2001; Hansen, 2002; Hansen et al., 2009; McIntosh et al., 2007; Thomson et al., 2006). However, many studies that have been done on scientific climate and weather information in Africa cite gaps that still exist between information provided and information desired, including challenges such as inaccurate forecasts, inadequate access to information as a barrier to utilization of internet data, lack of climate data, little meaningful use of the information (policies, planning, decision making at a higher level), products not well developed (some data have not been digitized) low skills, and lack of adequate timing for information dissemination (Frimpong, 2013).

Inaccurate forecasts remain a major challenge to effective use of seasonal forecasts by farmers and other users in southern Africa. Forecasts accuracy tends to decrease with smaller regions and locally specific information tends to be more uncertain and making this information more accurate requires sufficient observational records in order to be meaningful (Goddard et al., 2010; Gong et al., 2003). Inaccurate forecasts have been implicated in negative yield impacts and the opportunity costs for uncertain forecast is substantial and compromises profitability (Kolawole et al., 2014; Roudier et al., 2014). Farmers in Zimbabwe, and in eastern Africa, have demonstrated that, with some help, they are able to understand and incorporate probabilistic forecast information into their decision making processes (Ingram et al., 2002; Luseno et al., 2003; Lybbert et al., 2007; Patt, 2001; Suarez \& Patt, 2004). Therefore, much more work needs to be done in engaging farmers directly on interpreting seasonal climate forecasts correctly.

Limited and inequitable access to forecast information by farmers compounds the problems of efficiency of seasonal forecasts (Kolawole et al., 2014; Mapfumo et al., 2015; Mberego \& Sanga-Ngoie, 2012; Roncoli et al., 2002; Roncoliet al., 2009; Roudier et al., 2014). Therefore, there is need to improve the effectiveness of communication of climate information through multiple channels and deliberately partnering with the media for this cause since widespread communication failures constrain access to and therefore widespread uptake of information (Goddard et al., 2010; Hansen et al., 2009). Access to climate information is to a large extent a function of the density of meteorological stations in an area (Ogallo, 2010).

There is little evidence to show that seasonal climate forecast information is being meaningfully put to use and embedded in policies, planning or decision-making within the socio-economic sectors, even in cases where these sectors received vast amounts of information resulting from the seasonal forecasts (Goddard et al., 2010). There is need to generate useful climate information and predictions and translate that information into usable forms for decision makers through continued dialogues among users of the information periodically. Information tends to be applicable to relatively large areas and lacks specificity, including the fact that information is disseminated late and in unfriendly languages, with technical jargon that makes it limit the effectiveness of uptake (Goddard et al., 2010; Hansen et al., 2009; Kolawole et al., 2014; Van Aalst et al., 2008 cited in Mapfumo et al., 2015; Mberego \& Sanga-Ngoie, 2012; Patt \& Gwata, 2002). There is also lack of specific information about timing of rainfall and season onset or length, including the late dissemination of the information (Hansen et al., 2011; Kolawole et al., 2014).

Some of the available forecasts of extremes are not well developed, are not digitalized andare presented as typical probabilities rather than risk of these extremes, a challenge presented by the embryonic state of seasonal forecast systems at many centres (Goddard et al., 2010; Ogallo, 2010). Up to date, forecasters have not accounted for shortcomings such as models not currently representing important modes of intra-seasonal-to-interannual variability, in addition to ENSO predictions that have been encouraging to this point (Goddard et al., 2010). In certain situations, misinterpretation may lead to model predictions conflicting with official consolidated forecasts and the lack of easily available data and overestimated probabilities tend to reduce the actual use of many of these predictions and the usefulness of applications (Chidzambwa \& Mason, 2008; Goddard et al., 2010). Although there is evidence of increasing skill in seasonal forecasting in Africa, availability of seasonal forecast on the internet is likely to include statements that may be construed through inexpert interpretation of limited inputs (Goddard et al., 2010), indicating that there is need to better channel climate information. Essentially, a low relevant skills base still makes it difficult to simulate convective precipitation that produces torrential rainfall, leading to the difficulties faced by climate scientists.

The major point regarding most of the problems highlighted in this section is that these problems are symptomatic of inadequate policies and institutional process, and are therefore amenable to intervention (Mberehgo \& Sanga-Ngoie, 2012). Three key elements are identified as crucial for influencing action; technical quality of the information, relevance of this information to the needs of decision makers and perception that the information suits users' interests (Cash \& Buizer, 2005; Cash et al., 2006). 


\section{Indigenous Knowledge Systems Seasonal Forecasts}

Given the significant gaps in scientific knowledge, ethno-meteorological knowledge plays a key role in farmers' ability to devise climate variability and change adaptation measures. There is evidence to show that naturally, farmers have an inclination towards indigenous forecasts as opposed to scientific forecasts as they value their experiences over the years (Kolawole et al., 2014; Roudier et al., 2014). Farmers rely on historical patterns, weather observations and signs to formulate expectations on weather and climate (Orlove et al., 2010).

There are advantages that seem to emerge in studies done in South Africa, Zimbabwe and Botswana regardingindigenous forecasts; reliance on indigenous prediction indicatorsand, developing agricultural strategies in response to predictions (choice of crop varieties, land management strategies, and livestock species and management strategies), sometimes without consulting any other sources of predictions (Brooks et al., 2011; Orlove \& Kabugo, 2005). Indigenous knowledge has a strong practical emphasis that is oriented towards planning, and exhibits dynamism that allows for incorporation of new elements (Flavier et al., 1995; Kolawole et al., 2014; Orlove et al., 2010). These studies in Malawi, Botswana, and Uganda highlight the social nature of indigenous knowledge and shows that indigenous knowledge on forecast tends to be more accessible given that elders, who are predominantly custodians of this knowledge command respect in their communities and their stock of personal experience is considered to be valuable (Briggs \& Moyo, 2012; Kolawole et al., 2014; Orlove et al., 2010; Roncoli et al., 2002). Moreover, farmers tend to share their experiences and knowledge on forecasts with others at a larger scale and give them a sense of the arrival and progress of the rains (Orlove et al., 2010). Farmers in Malawi and Botswana highlight that indigenous forecasts tend to bemore accurate and simple to understand to farmers as opposed to the complex nature of scientific forecasts that require sophisticated equipment and formal education and training and financial investment (Briggs \& Moyo 2012; Kolawole et al., 2014; Onyango, 2009; Ouma, 2009).

Farmers use tree phenology, animal behaviour, wind circulation, cloud cover and other social indicators to predict rains and season quality. Farmers are particularly interested in when the rainy season will start so they make preparations. They are also concerned with the quality of the season so they make decisions of what to grow.

\subsection{Tree Phenology Indicators}

Table 1 shows some of the vegetation indicators used in southern Africa to predict rainfall.Studies have for the past decade started to show that there are already shifts in the flowering patterns of trees to El Niño events (Curran et al., 1999). This brings to mind the implications of shifting tree patterns to traditional indicators that are critical for seasonal forecasting (see Table 1). Studies done in southern Africa highlight that if certain trees bear fruit at certain periods of time then this indicates either a good or poor rainfall season, for instance, in Botswana, a certain shrub called Moretlhwa and known in English as Brandy bush/Raisin bush (Grewiaflava) bears fruits twice a year. Early fruiting (November to early December) indicates low rainfall and late fruiting (February/March) indicates a good season and no fruit at all indicates a serious drought (Kolawole et al., 2014). In Zimbabwe the disappearance and delayed fruiting of trees such as Maroro, Tsambatsi and Hute and on the other hand the profuse fruiting of the Muhacha tree, including the delayed regrowth of grasses from August to Octobers have for a long time indicated droughts to come (Mapfumo et al., 2015). Coffee cultivation in Uganda was not common until the 1940s, and so the habit of observing the flowering of the coffee tree as a sign for the onset of the rain must have developed after this time (Orlove et al., 2010). Signs that there will be rains in a few weeks include the flowering of trees, especially coffee trees in Uganda (Orlove et al., 2010). Hence, the shifting of tree fruiting patterns is likely to render this indicator less reliable. The reliability of the indicators that have been highlighted in reviewed studies is critical since indigenous forecasts are a significant part of the prediction of climate parameters for smallholder farming systems. It is also important to understand the significance of the indigenous forecasts for planning purposes at this level.

It is also important to note the robustness of indigenous indicators across the region (Tables 1, 2 and 3). The commonality of these indicators across ecozones from Tanzania in the east to South Africa in the south is critical with regard to preservation of certain ecosystems. The use of these robust indicators alludes to the necessity to preserve and protect the trees and animals bearing these indicators. 
Table 1. Indigenous indicators for weather and climate in southern Africa- tree phenology

\begin{tabular}{|c|c|c|c|}
\hline Indicator & Country & Significance & Reference \\
\hline \multicolumn{4}{|l|}{ Onset of the rains } \\
\hline \multirow{5}{*}{$\begin{array}{l}\text { Flowering of the peach tree } \\
\text { (Prunus persica), apricot } \\
\text { (Prunus armeniaca), budding of } \\
\text { acacia species }\end{array}$} & Botswana & \multirow[t]{5}{*}{ Beginning of rainy season } & Kolawole et al., 2014 \\
\hline & Malawi & & Joshua et al., 2011 \\
\hline & Zambia & & Mugabe et al., 2010 \\
\hline & Zimbabwe & & Risiro et al., 2012; Mapfumo et al., 2015 \\
\hline & South Africa & & Zuma-Netshiukhwi et al., 2013 \\
\hline \multicolumn{4}{|l|}{ Season Quality } \\
\hline \multirow{6}{*}{$\begin{array}{l}\text { Behavior of certain plants: } \\
\text { sprouting of Aloe ferox; } \\
\text { Germination of new leaves on } \\
\text { baobab and tamarind trees }\end{array}$} & Bostwana & Indication of good rains; & Mogotsi et al., 2011 \\
\hline & Malawi & Abundance & Joshua et al., 2011 \\
\hline & South Africa & of wild fruits such as & Zuma-Netshiukhwi et al., 2013 \\
\hline & Swaziland & Vangueria infausta, & Mugabe et al., 2010 \\
\hline & Zimbabwe & Englerophytumnatalense and Scleroc aryacaffra & UNEP, 2008; Dube \& Musi, 2002 \\
\hline & Zambia & $\begin{array}{l}\text { during the months of December to February } \\
\text { signify an imminent challenging farming season }\end{array}$ & \\
\hline \multirow{3}{*}{$\begin{array}{l}\text { Mango tree (Mangifera indica); } \\
\text { Nandi Flame tree (Delonixregia) }\end{array}$} & Malawi & \multirow{3}{*}{$\begin{array}{l}\text { Heavy flowering of the mango trees indicate a } \\
\text { potential drought season }\end{array}$} & Joshua et al., 2011 \\
\hline & Tanzania & & Risiro et al., 2012 \\
\hline & Zimbabwe & & Kijazi et al., 2012; UNEP, 2008 \\
\hline \multirow{5}{*}{$\begin{array}{lr}\text { Parinari } & \text { curatellifolia } \\
\text { (muhacha), Lannea discolor } \\
\text { (gan'acha), Uapaca kirkiana } \\
\text { (mushuku); Boscia albitrunca; } \\
\text { Adansonia digitata }\end{array}$} & Botswana & \multirow{5}{*}{$\begin{array}{l}\text { Heavy flowering of the trees indicate a potential } \\
\text { drought season }\end{array}$} & Mogotsi et al., 2011 \\
\hline & Malawi & & Joshua et al., 2011 \\
\hline & Zambia & & Mugabe et al., 2010 \\
\hline & Zimbabwe & & Muguti \& Maposa, 2012 \\
\hline & & & Risiro et al., 2012 \\
\hline \multirow{3}{*}{$\begin{array}{l}\text { Dormancy breaking in certain } \\
\text { treesspecies e.g. Brachystegia } \\
\text { boehmii (mupfuti) }\end{array}$} & Malawi & \multirow[t]{3}{*}{ Indicates plenty of rain in a few days } & Joshua et al., 2011 \\
\hline & Zambia & & Mugabe et al., 2010 \\
\hline & Zimbabwe & & Muguti \& Maposa, 2012 \\
\hline $\begin{array}{l}\text { Dropping off of young avocado } \\
\text { fruits }\end{array}$ & Swaziland & Challenging farming season & UNEP, 2008; Dube \& Musi, 2002 \\
\hline
\end{tabular}

\subsection{Animal Behavior Indicators}

The singing, nesting and chirping of certain birds appears to be a useful indicator for the onset of the rains in southern Africa (UNEP, 2008). In addition, there are signs that there will be a lot of rains through the arrival of migratory birds, particularly the southern hornbill (Bucorvusa byssinicus) in Zimbabwe, Zambia and northern parts of South Africa (Orlove et al., 2010) with use of the movements of fronts to provide them with tailwinds (Liechti, 2006). Sounds from certain insects that emerge from overwintering/hibernation (Mapfumo et al., 2015) tend to signal the start of a season and planning by farmers in Botswana and Zimbabwe. Table 2 shows some of the indicators based on animal behaviour. It should be noted that there are indicators that are common in most southern Africa countries. This assists in preservation of various animals across the region. 
Table 2. Indigenous indicators for weather and climate in southern Africa-animal behaviour

\begin{tabular}{|c|c|c|c|}
\hline Indicator & Country & Significance & Reference \\
\hline \multicolumn{4}{|l|}{ Onset of the rains } \\
\hline \multirow{5}{*}{$\begin{array}{l}\text { Appearance of red ants, rapidly } \\
\text { increasing size of anthills, moist } \\
\text { anthills (October-November) }\end{array}$} & South Africa & \multirow[t]{5}{*}{ Good rains are coming } & Zuma-Netshiukhwi et al., 2013 \\
\hline & Malawi & & Mugabe et al., 2010 \\
\hline & Tanzania & & Kijazi et al., 2012; UNEP, 2008 \\
\hline & Zambia & & Joshua et al., 2011 \\
\hline & Zimbabwe & & Risiro et al., 2012 \\
\hline \multirow{7}{*}{$\begin{array}{l}\text { First appearance of sparrows; flock of } \\
\text { swallows (Psalidoprocne pristoptera) } \\
\text { preceding dark clouds }\end{array}$} & Botswana & \multirow{7}{*}{$\begin{array}{l}\text { Rain is at hand and farmers should } \\
\text { prepare for above normal rains }\end{array}$} & Mogotsi et al., 2011 \\
\hline & Malawi & & Joshua et al., 2011 \\
\hline & South Africa & & Zuma-Netshiukhwi et al., 2013 \\
\hline & Swaziland & & Mugabe et al., 2010 \\
\hline & Tanzania & & Risiro et al., 2012 \\
\hline & Zambia & & Kijazi et al., 2012; UNEP, 2008; \\
\hline & Zimbabwe & & Dube \& Musi, 2002 \\
\hline \multirow{3}{*}{$\begin{array}{l}\text { Appearance of certain birds e.g. stock, } \\
\text { Quelia }\end{array}$} & Malawi & \multirow{6}{*}{$\begin{array}{l}\text { Rain is at hand and farmers should } \\
\text { prepare for above normal rains }\end{array}$} & Joshua et al., 2011 \\
\hline & Zimbabwe & & Muguti \& Maposa, 2012 \\
\hline & Botswana & & Risiro et al., 2012 \\
\hline \multirow{3}{*}{$\begin{array}{l}\text { Singing, nesting and chirping of } \\
\text { certain birds }\end{array}$} & Zambia & & Mogotsi et al., 2011 \\
\hline & Tanzania & & Mugabe et al., 2010 \\
\hline & & & Kijazi et al., 2012; UNEP, 2008 \\
\hline $\begin{array}{l}\text { Cry of the phezukwemkhono (Cuculus } \\
\text { solitarius) bird }\end{array}$ & Swaziland & $\begin{array}{l}\text { This signals the start of the wet season } \\
\text { in August-November. }\end{array}$ & UNEP, 2008 \\
\hline \multirow{4}{*}{$\begin{array}{l}\text { Termite appearance } \\
\text { (Ancistrotermes spp and Macrotermes } \\
\text { spp) }\end{array}$} & Botswana & \multirow{4}{*}{$\begin{array}{l}\text { Appearance of many termites indicate } \\
\text { near rainfall onset }\end{array}$} & Mogotsi et al., 2011 \\
\hline & Malawi & & Joshua et al., 2011 \\
\hline & Zambia & & Mugabe et al., 2010 \\
\hline & Zimbabwe & & Muguti \& Maposa, 2012 \\
\hline \multirow{3}{*}{$\begin{array}{l}\text { Frogs in swampy areas croaking at } \\
\text { night }\end{array}$} & Swaziland & \multirow[t]{3}{*}{ Indicator for onset of rains } & UNEP, 2008; Dube \& Musi, 2002 \\
\hline & Zambia & & Mugabe et al., 2010 \\
\hline & Zimbabwe & & Muguti \& Maposa, 2012 \\
\hline \multirow[t]{2}{*}{ Rock rabbit } & Zimbabwe & \multirow{2}{*}{$\begin{array}{l}\text { Its unusual squeaking indicates } \\
\text { imminent rainfall }\end{array}$} & Muguti \& Maposa, 2012 \\
\hline & & & Risiro et al., 2012 \\
\hline \multirow{4}{*}{$\begin{array}{l}\text { Cicadas (nyenze), day flying chafers } \\
\text { (mandere), dragon flies (mikonikoni) }\end{array}$} & Malawi & \multirow{4}{*}{$\begin{array}{l}\text { Appearance of these signifies } \\
\text { imminent rainfall }\end{array}$} & Joshua et al., 2011 \\
\hline & Zambia & & Mugabe et al., 2010 \\
\hline & Zimbabwe & & Muguti \& Maposa, 2012 \\
\hline & & & Risiro et al., 2012 \\
\hline \multicolumn{4}{|l|}{ Season Quality } \\
\hline \multirow{3}{*}{$\begin{array}{l}\text { Grunting of pigs and behaviour of } \\
\text { peacocks, doves and ducks, indicate } \\
\text { low humidity }\end{array}$} & Tanzania & \multirow[t]{3}{*}{ Rains are near } & Kijazi et al., 2012 \\
\hline & Swaziland & & UNEP, 2008; Dube \& Musi, 2002 \\
\hline & South Africa & & Zuma-Netshiukhwi et al., 2013 \\
\hline \multirow[t]{2}{*}{ Calves jumping happily } & Swaziland & \multirow[t]{2}{*}{ Good rain season } & UNEP, 2008; Dube \& Musi, 2002 \\
\hline & South Africa & & Zuma-Netshiukhwi et al., 2013 \\
\hline \multirow{2}{*}{$\begin{array}{l}\text { Certain snakes moving down the } \\
\text { mountain }\end{array}$} & Zambia & \multirow[t]{2}{*}{ Good rain season } & Mugabe et al., 2010 \\
\hline & South Africa & & Zuma-Netshiukhwi et al., 2013 \\
\hline Frequent appearance of tortoises & South Africa & Good rain season & Zuma-Netshiukhwi et al., 2013 \\
\hline \multirow{2}{*}{$\begin{array}{l}\text { Appearance of certain insects e.g. } \\
\text { millipedes, spiders }\end{array}$} & Malawi & \multirow[t]{2}{*}{ Indicates coming of heavy rains } & Joshua et al., 2011 \\
\hline & Zimbabwe & & Risiro et al., 2012; Mapfumo et al., 2015 \\
\hline
\end{tabular}




\begin{tabular}{|c|c|c|c|}
\hline $\begin{array}{l}\text { Increased appearance of elephants } \\
\text { (Loxodonta africana) near watering } \\
\text { points meant for livestock }\end{array}$ & Botswana & Indicator of low rainfall & Mogotsi et al., 2011 \\
\hline $\begin{array}{l}\text { Nesting of the emahlokohloko bird } \\
\text { (Ploceus spp) }\end{array}$ & Swaziland & $\begin{array}{l}\text { If nesting is done high up in the trees } \\
\text { next to the river, floods are } \\
\text { anticipated, and vice versa }\end{array}$ & UNEP, 2008; Dube \& Musi, 2002 \\
\hline $\begin{array}{l}\text { When the umfuku (Centropus } \\
\text { burchellie) bird chirps during the } \\
\text { farming season (October to April) }\end{array}$ & Swaziland & $\begin{array}{l}\text { This is a sign of a thunderstorm } \\
\text { approaching. }\end{array}$ & UNEP, 2008 \\
\hline Increase in swarms of bees & Tanzania & Sign of a wet season & $\begin{array}{l}\text { Kijazi et al., } 2012 \\
\text { UNEP, } 2008\end{array}$ \\
\hline $\begin{array}{l}\text { Abundance } \\
\text { of butterflies (Danaus plexippus) } \\
\text { during the farming season, presence of } \\
\text { army worms (Spodoptera exempta) }\end{array}$ & Swaziland & $\begin{array}{l}\text { Indicate imminent mid-season drought } \\
\text { and possible famine }\end{array}$ & UNEP, 2008 \\
\hline Goat intestines & Tanzania & $\begin{array}{l}\text { If the goat intestines are empty at } \\
\text { slaughter it indicates drought or } \\
\text { famine ahead, and vice versa }\end{array}$ & $\begin{array}{l}\text { Kijazi et al., } 2012 \\
\text { UNEP, } 2008\end{array}$ \\
\hline Libido of donkeys & Tanzania & $\begin{array}{l}\text { Increased libido of donkeys } \\
\text { (August-October) indicate below } \\
\text { normal rain and drought in the coming } \\
\text { season }\end{array}$ & $\begin{array}{l}\text { Kijazi et al., } 2012 \\
\text { UNEP, } 2008\end{array}$ \\
\hline Mating of goats & Tanzania & $\begin{array}{l}\text { Increased mating of goats } \\
\text { (August-September) indicate more } \\
\text { rain in the coming season }\end{array}$ & $\begin{array}{l}\text { Kijazi et al., } 2012 \\
\text { UNEP, } 2008\end{array}$ \\
\hline
\end{tabular}

\subsection{Atmospheric Indicators and Indigenous Forecasting}

Table 3 shows some of the indicators based on atmospheric air circulation. Farmers in southern Africa believe that there is significant merit in the sequencing of seasons as an indicator for what the coming season will be like (Orlove et al., 2010; Mapfumo et al., 2015). Essentially, indigenous forecasting is not solely based on personal experience but also on trend analysis (Kolawole et al., 2014; Mapfumo et al., 2015). Mapfumo et al. (2015) cite a case of farmers in Zimbabwe who have traced the changes in five rainfall regimes that had for ages indicated the specific stages of rainfall such as the onset of the winter season at the end of May, rains coming in August after the processing of grains, late September marking the end of wild fires, hastening growth of new tree leaves in October and marking the beginning of the rainy season in October/November. These case studies show that the traditional indicators have also been affected by changes in rainfall patterns to an extent that they may mislead farmers and not be as reliable as they used to be. Farmers rely on these indicators for farming practices including securing marketing and trade arrangements for food security (Mapfumo et al., 2015).

The onset of rains from a few days to a few weeks is indicated by an increase in night-time temperatures, shifts in direction of prevailing winds, particular phases of the moon and the appearance of strong whirlwinds, changes in smell of the environment, all highlighted as happening just before the rains (Ajibade \& Shokemi, 2003; Orlove et al., 2010; Kolawole et al., 2014; Mapfumo et al., 2015). However, there are certain inconsistencies in one community in Uganda on the exact indications of onset of rains through wind direction as some farmers look for a change in wind direction from easterlies to westerlies while others look for a shift from southerlies to northerlies (Orlove et al., 2010). In terms of the moon, there are inconsistencies on whether it is the dark phase of the moon or the waning of the moon that indicates the onset of the rain. Although many farmers have expressed a high level of confidence in traditional indicators for a rainfall season (Orlove et al., 2010; Roudier et al., 2014), the highlighted inconsistencies give pointers to a degree of inaccuracy of some of these indigenous indicators. However, there still exists a significant level in some of these indicators that have been explained in scientific terms, for instance the Inter-tropical Convergence Zone in March in the same area explains the nighttime temperature shifts and other scientific forecast (Kolawole et al., 2014; Roncoli et al., 2002). These temperature fluctuations are also used in West Africa as an indication of the occurrence of a rain event within days (Roudier, 2014). 
Table 3. Indigenous indicators for weather and climate in southern Africa-atmospheric circulation

\begin{tabular}{|c|c|c|c|}
\hline Indicator & Country & Significance & Reference \\
\hline \multicolumn{4}{|l|}{ Onset of the rains } \\
\hline \multirow[t]{4}{*}{ Moon phases } & South Africa & \multirow{4}{*}{$\begin{array}{l}\text { moon crescent facing upwards indicates } \\
\text { upholding water and when facing } \\
\text { downwards is releasing water in the next } \\
\text { three days }\end{array}$} & Zuma-Netshiukhwi et al., 2013 \\
\hline & Malawi & & Joshua et al., 2011 \\
\hline & Zambia & & Mugabe et al., 2010 \\
\hline & Zimbabwe & & Shoko \& Shoko, 2013 \\
\hline \multirow[t]{6}{*}{ Star constellation } & Botswana & \multirow{6}{*}{$\begin{array}{l}\text { Star pattern and movement from west to } \\
\text { east at night under clear skies means } \\
\text { rain will fall in } 3 \text { days }\end{array}$} & Mogotsi et al., 2011 \\
\hline & Malawi & & Joshua et al., 2011 \\
\hline & Swaziland & & Mugabe et al., 2010 \\
\hline & Zambia & & Shoko \& Shoko, 2013 \\
\hline & Zimbabwe & & Zuma-Netshiukhwi et al., 2013 \\
\hline & South Africa & & UNEP, 2008; Dube \& Musi, 2002 \\
\hline \multicolumn{4}{|l|}{ Season Quality } \\
\hline \multirow[t]{5}{*}{ Moon profuse halo } & South Africa & Good rains & Zuma-Netshiukhwi et al., 2013 \\
\hline & Malawi & Disposition of the new moon indicates & Joshua et al., 2011 \\
\hline & Tanzania & more disease and erratic rainfall & Kijazi et al., 2012 \\
\hline & Zambia & & Mugabe et al., 2010 \\
\hline & Zimbabwe & & Shoko \& Shoko, 2013; Risiro et al., 2012 \\
\hline \multirow[t]{7}{*}{ Wind swirls } & Botswana & \multirow{7}{*}{$\begin{array}{l}\text { Frequent appearance is a sign of good } \\
\text { rains }\end{array}$} & Mogotsi et al., 2011; Joshua et al., 2011 \\
\hline & Malawi & & Mugabe et al., 2010; Kijazi et al., 2012 \\
\hline & Swaziland & & UNEP, 2008; Dube \& Musi, 2002 \\
\hline & Tanzania & & Muguti \& Maposa, 2012 \\
\hline & Zambia & & Zuma-Netshiukhwi et al., 2013 \\
\hline & Zimbabwe & & Risiro et al., 2012 \\
\hline & South Africa & & \\
\hline Mist-covered mountains & South Africa & Signal of good rains & Zuma-Netshiukhwi et al., 2013 \\
\hline \multirow[t]{5}{*}{ Temperature } & Botswana & \multirow{5}{*}{$\begin{array}{l}\text { Heat in low areas in August indicate } \\
\text { there will be more rainfall in the coming } \\
\text { season; high temperature in October and } \\
\text { November signifies near onset and a } \\
\text { good rain season. }\end{array}$} & Mogotsi et al., 2011 \\
\hline & Malawi & & Joshua et al., 2011 \\
\hline & Tanzania & & Kijazi et al., 2012 \\
\hline & Zambia & & UNEP, 2008; Mugabe et al., 2010 \\
\hline & Zimbabwe & & Shoko \& Shoko, 2013; Risiro et al., 2012 \\
\hline \multirow{5}{*}{$\begin{array}{l}\text { Appearance of many nimbus } \\
\text { clouds; appearance of red clouds in } \\
\text { the morning }\end{array}$} & Malawi & Indicators for rain in 1-3 days & Joshua et al., 2011 \\
\hline & Swaziland & & Mugabe et al., 2010 \\
\hline & Tanzania & & Kijazi et al., 2012 \\
\hline & Zambia & & UNEP, 2008; Dube \& Musi, 2002 \\
\hline & Zimbabwe & & Risiro et al., 2012 \\
\hline \multirow{3}{*}{$\begin{array}{l}\text { Appearance of fog/haze in the } \\
\text { morning }\end{array}$} & Malawi & Indicator for no rain & Joshua et al., 2011 \\
\hline & Zambia & & Mugabe et al., 2010; Risiro et al., 2012 \\
\hline & Zimbabwe & & \\
\hline
\end{tabular}

\subsection{Other Natural Resources Indicators}

Although natural resource based indicators featured in reviewed studies, these indicators are not as common as the others in terms of predicting the coming season. However, it is noted that the natural resource based indicators still play a significant role in predicting the seasons (Kolawole et al., 2014; Mapfumo et al., 2015; Roncoli et al., 2002). The nature of major rivers, springs and streams and changes in behavior of major resource pools remains important in indicating what the coming season will be (Mapfumo et al., 2015). A one-directional free flow of the river indicates an abundant rains season while rivers flowing in a spiral-like manner tends to indicate a season of limited rainfall (Kolawole et al., 2014). A justification for these river flow behaviours are 
couched in the logic that free flow indicates plenty of rains upstream while a spiral movement of river flow emanating from a rivers gradually drying up when they receive less rainfall (Kolawole et al., 2014).

Table 4. Other indigenous indicators for weather and climate in southern Africa

\begin{tabular}{|c|c|c|c|}
\hline Indicator & Country & Significance & Reference \\
\hline Rainmaking ceremonies & $\begin{array}{l}\text { Botswana } \\
\text { Zimbabwe }\end{array}$ & $\begin{array}{l}\text { Praying and traditional healers } \\
\text { consulting the gods }\end{array}$ & $\begin{array}{l}\text { Mogotsi et al., } 2011 \\
\text { Vijfhuizen, } 1997\end{array}$ \\
\hline $\begin{array}{l}\text { Body feels increased or excessive heat during the night } \\
\text { and day; a feeling of body pain (headache, flu, } \\
\text { backaches) }\end{array}$ & Zimbabwe & Indicator for rain in 1-3 days & Risiro et al., 2012 \\
\hline Asthmatic attack, painful operations & Zimbabwe & $\begin{array}{l}\text { Imminent cold weather and } \\
\text { humid conditions }\end{array}$ & Risiro et al., 2012 \\
\hline
\end{tabular}

\section{Potential for Integration of Indigenous Knowledge with Climate Science}

While there are differences in criteria used to define seasonal phenomena by both farmers and scientists, there is a significant overlap between indigenous and scientific knowledge regarding weather and climate forecasts (Hinkel et al., 2007; Kolawole et al., 2014; Laidler \& Ikummaq, 2008), making indigenous knowledge potentially useful for scientific forecasting, particularly in tracking change. Moreover, both local and scientific knowledge in weather forecasting are produced through observation, experimentation and validation, suggesting that there is a meeting point between the two forms of knowledge, although there is an acknowledgement that indigenous knowledge is devoid of any regimentation and regulations and entails a measure of spirituality that is absent in scientific forecast (Kolawole et al., 2014). Therefore, there is need for a suitable platform where farmers and scientists can work together and to enable them devise adaptation strategies against climate change and variability.

Studies show that generally, farmers are open and willing to integrate new information into their traditional forecasting methods as demonstrated by these farmers readiness to engage, discuss and use modern scientific forecasts (Orlove et al., 2010). This openness and interest could work well for climate scientists as this could allow them to design forecasts that would be in sync with farmers' priorities and more acceptable to these farmers (Nyong et al., 2007). For instance, climate scientists' current system rests on a coarse spatial analysis that does not address the risks in drier sub-regions within relatively moist regions, providing an opportunity for incorporation of indigenous knowledge of spatial variability in climate patterns for the identification of areas at risk for drought (Orlove et al., 2010).

Scientific forecasting information is not embraced by the smallholder farmers due to a number of reasons. Lack of a sense of ownership by farmers and decision makers alike has contributed to the limited uptake of the disseminated meteorological information. For this and other reasons, climate scientists are increasingly under pressure to transcend their disciplinary confines and engage in a process of joint, continued and participatory learningwith users of the information and encourage effective outreach programmes for the information to realise its full potential (Glatnz, 2003, 2005; Goddard et al., 2010).

A tripartite arrangement between users, scientists (cross disciplinary) and policy makers is important to create partnerships that maximize use of available climate information through the near-universal use of indigenous climate indicators, and building culturally relevant analogies of decisions under uncertainty into the climate communication process (Kolawole et al., 2014; Ogallo, 2010; Phillips \& Orlove, 2004; Sivakumar, 2006; Suarez \& Patt, 2004). This can be done through contact workshops, public lectures and through the mass media (Kolawole et al., 2014). This is a more viable alternative model to that which casts climate scientists in an active role as "sources of knowledge" and the farmers in a passive role as "recipients of forecasts" (Orlove et al., 2010). The social nature of indigenous knowledge presents an opportunity for national meteorological services to develop new means of communication for their forecast products where farmers can participate as agents as well as consumers as well as for farmers themselves to understand and develop an interest to act on forecast information (Orlove et al., 2010; Roncoliet al., 2005; Roncoli et al., 2009; Suarez \& Patt, 2004).

\section{Challenges Facing IKS and Potential Integration with Scientific Knowledge}

It is important to highlight that it would be naïve to believe that indigenous knowledge forecasting is without its 
challenges. Three areas in which indigenous knowledge for weather and climate forecasting faces challenges are: negative perceptions regarding indigenous knowledge, erosion due to modernization and disruption of the traditional indicators by changes in weather and climate. There is a tendency to perceive local knowledge and practices as impediments to the success of externally funded projects related to agriculture and imposed on the poor communities. In addition, policymakers on the continent tend to view reliance on indigenous knowledge for climate forecasting with skepticism (Briggs \& Moyo, 2012; Saitabau, 2014). And for this and other reasons, countries in southern Africa are still at knowledge stage rather than at a conceptual stage where there is implementation or use of this knowledge for smallholder farmer productivity (Saitabau, 2014). Essentially, there is need for serious engagement with communities before implementation of development intervention to take into account local knowledge for enhanced productivity, particularlyderiving response farming approaches with both the extension office and farmers participating (F. Berkes \& M. Berkes, 2009; Briggs \& Moyo, 2012; Mberego \& Sanga-Ngoie, 2012; Sillitoe \& Marzano, 2008).

The local systems have come under threat from modernization with local custodians of knowledge now viewed as 'backward charlatans' (Onyango, 2009; Ouma, 2009). On the other hand, scientific knowledge for climate forecasting is considered to be superior and currently enjoys a dominant position as a privileged knowledge as opposed to the 'conservative' and 'backward' knowledge that farmers rely on. This explains the suggestion that there is need to document indigenous knowledge in the context of weather and climate forecasting (Goddard et al., 2010; Ouma, 2009) in order to maintain its relevance in the face of accelerated modernization. Individuals and societies tend to have short-term memories, yet they have to rely on these memories for climate forecasting (Glantz, 2003; Mberego \& Sanga-Ngoie, 2012). Documentation of local knowledge in both local languages and English becomes vital for adequate information sharing and for the preservation of traditional indicators that have proven to be useful for smallholder farmers, given that few people's indigenous knowledge is in-depth and the elders as the custodians of this knowledge are dying out without passing down the knowledge as was the case in the past (Kolawole et al., 2014).

Documentation becomes even more critical given that climate variability and change has affected some of the indigenous indicators, placing limits on the scope of these indicators as a basis for decision making (Mapfumo et al., 2015). This emerging thinking of the disruption of traditional indicators by climate change is also based on the waning of the natural resource base upon which the knowledge is built, which is worrisome given the increasing demands for adaptation to climate variability and change (Mapfumo et al., 2015). For instance, biotic resources have adapted themselves to changing climatic conditions and abrupt changes in weather patterns, modifying themselves in the process and making it increasingly difficult to anticipate certain patterns in their behavior (Boko et al., 2007; Mapfumo et al., 2015; Ouma, 2009).

Scientific knowledge had over the past decades increasingly taken priority over local knowledge and practice in agricultural systems research and development (Walker et al., 1999). For instance, early warning systems on disasters and climate related shocks were traditionally channeled through religious and cultural methods such as oral literatures, poems and songs, which had unfortunately lost recognition and utilization in the context of climate change adaptation in the same period. However, in recent years, particularly in the past decade, there is an emerging and dominant view that places emphasis on local knowledge as a key component of an agricultural system and the view that instead, scientific knowledge must enhance local knowledge, rather than displace it (Jain, 2014; Joshua et al., 2011; Maconachie, 2012; Osbahr \& Allan, 2003). Despite this shift towards recognition of IKS in climate change adaptation in agriculture systems, there is evidence to show that increased rainfall variability and temperatures have reduced smallholder farmers' confidence in indigenous knowledge, hence reducing these farmers' adaptive capacity and increasing their vulnerability to climate change (Joshua et al., 2011). In addition, skewed use of scientific knowledge and weather and climate predictions has proven to be a major constraint for farm level decision making as they do not incorporate IK, which farmers already live with. In the same context, farmers are more willing to use seasonal climate forecasts when these forecasts are presented with and compared to the local indigenous climate forecasts (Gana, 2003; Patt \& Gwata, 2002). This would increase resilience and adaptive capacity (Figure 1).

\section{Social Capital and Indigenous Knowledge Adaptation Systems}

In southern Africa, spiritual rainmaking ceremonies have been at the heart of many smallholder traditional societies and their interaction with nature when inducing rain and blessings in the agricultural enterprise (Vijfhuizen, 1997). Ritual performers would conduct prayers, use medicine portions, brew and drink traditional beer, dance under trees among other activities in manipulating the falling of rain. These acts were known for yielding positive results to the autochthonous people. The success of the performed rituals was guaranteed because they were conducted in a deeply rooted and synchronised cosmological condition with an intricate 
connection between moral geography, the whole environment and the spirits surrounding them (Vijfhuizen, 1997). Current calls by traditionalists in conjunction with politicians and social scientists to rejuvenate spiritual rainmaking as one of the panacea to current weather and climate hazards affecting modern societies have received intensive criticism from bio-physical (pro-scientific) and Christian based standpoints (Memmott, 2010). Bio-physical scientists jettison the rituals as anachronistic and redundant practices with no tangible results. Their argument is premised on the assumption that there is no symbiotic relationship between brewing traditional beer, dancing under trees and use of medicine objects and the falling of rain. The bio-physical views are deeply rooted on the premise of science to predict and manipulate both short term and long term climate. In other instances they have the power to influence weather patterns through artificial practices like cloud seeding among others.

There is need for further research especially in providing empirical evidence to support traditionalists and farmers' current claims of changes in seasonality and the role of spiritual ceremonies in reducing vulnerability (Mapfumo et al., 2015). This is an area in which climate (biophysical and social) scientists can collaborate with traditional farmers to provide integration of science and social capital. In addition, to date, less progress has been made in assessments of the extent and impact of forecast use, particularly among vulnerable populations, such as smallholder farmers in Africa. This becomes an interesting area for study that needs further explanation of how forecasts are used by smallholder farmers and to what extent this is really the case. Another area that needs further research and in which scientists can partner with farmers is in connecting the physical climate system to environmental indicators that farmers have highlighted in a number of documented studies (Goddard et al., 2010), integrated with use of indigenous knowledge and spiritual ceremonies.

\section{Adaptation Strategies}

Adaptation strategies employed by farmers are different depending on climatic stimuli and intervening conditions or non-climatic stimuli. The different stimuli influence the sensitivity of a particular system and the nature of adjustments or adaptation required. As a result adaptation measures need to consider socio-economic and institutional arrangements at a particular locality. Impacts of climate change are quite different depending on the socio-economic disposition of the farmers, and may require different adaptive responses both in the short and in the long term. The appropriateness of a particular adaptation strategy is highly dependent on time and place as they are influenced by key cultural and indigenous observations and indicators at the local level. These indigenous observations, while sometimes robust, are usually peculiar to a local area or region.

There are generally two approaches to adaptation. The first is an approach that advocates for actions that reduce existing vulnerability. The use of early warning systems, for instance, means individuals and communities are able to employ anticipatory adaptation. The second approach is to mainstream climate change into existing activities. Mainstreaming ensures that future vulnerability to climate change is countered by considering climate change in decision making. This is the trend in most developing countries where development is a priority. This approach is particularly useful where climate change may increase the risk of failure of assets. It is vital, therefore, to increase resilience, coping and adaptive capacity of natural and human systems, so as to prepare them for future variability and extremes due to climate change.

\section{Conclusions}

Scientific forecasts have to some extent failed to make an intended impact on smallholder farmers due to the inaccessibility and inequitable distribution of this information to smallholder farmers as the primary users of the information. The issue of injustices in the context of the dominance of scientific forms of forecasting against indigenous indicators that tend to be regarded as backward. While indigenous forecasting is not without its challenges, a lot more can be learnt and used to implement adaptation strategies that are long-lasting by integrating scientific forecasts with indigenous knowledge. This will likely lend legitimacy of these forecasts in the eyes of smallholder farmers. Certain inconsistencies in indigenous indicators, including shifts in phenological patterns and changes in indigenous indicators due to changes in rainfall patterns, all point to negative implications for traditional forecasting as a reliable method of forecasting. However, indigenous forecasting remains a sound entry point given its social nature and acceptability by smallholder farmers. Moreover, indigenous knowledge has a strong practical emphasis that is oriented towards planning, and exhibits dynamism that allows for incorporation of new elements; where scientific forecasts can then come in to complement and add credence to indigenous knowledge.

\section{References}

Agoumi, A. (2003). Vulnerability of North African countries to climatic changes: Adaptation and implementation strategies for climatic change. IISD/Climate Change Knowledge Network. Retrieved from http://www.cckn.net//pdf/north_africa.pdf 
Ajibade, L. T., \& Shokemi, O. O. (2003). Indigenous approach to weather forecasting in Asa L.G.A., Kwara State, Nigeria. Indilinga: African Journal of Indigenous Knowledge Systems, 2(1), 37-44.

Balaghi, R., Badjeck, M. C., Bakari, D., De Pauw, E., De Wit, A., Defourny, P., ... Tychon, B. (2010). Managing Climatic Risks for Enhanced Food Security: Key Information Capabilities. Procedia Environmental Sciences, 1, 313-323. http://dx.doi.org/10.1016/j.proenv.2010.09.020

Berkes, F., \& Berkes, M. (2009). Ecological complexity, fuzzy logic and holism in indigenous knowledge. Futures, 41, 6-12. http://dx.doi.org/10.1016/j.futures.2008.07.003

Boko, M., Niang, I., Nyong, A., Vogel, C., Githeko, A., Medany, M., ... Yanda, P. (2007). Africa: Climate Change 2007: Impacts, Adaptation and Vulnerability. In M. Parry, O. Canziani, J. Palutikof, P. Van Der, \& H. C. Linden (Eds.), Contribution of Working Group II to the Fourth Assessment Report of the Intergovernmental Panel on Climate Change. Cambridge, UK.

Briggs, J., \& Moyo, B. (2012). The Resilience of Indigenous Knowledge in Small-scale African Agriculture: Key Drivers. Scottish Geographical Journal, 128(1), 64-80. http://dx.doi.org/10.1080/14702541.2012.694703

Brooks, N., Anderson, S., Ayers, J., Burton I., \& Tellam, I. (2011). Tracking adaptation and measuring development. Retrieved from http://africanclimate.net/en/publications

Cabrera, V. E., Letson, D., \& Podestá, G. (2007). The value of the climate information when farm programs matter. Agricultural Systems, 93, 25. http://dx.doi.org/10.1016/j.agsy.2006.04.005

Cash, D. W., Borck, J. C., \& Patt, A. G. (2006). Countering the loading dock approach to linking science and decision making: comparative analysis of El Nino/Southern Oscillation (ENSO) forecasting systems. Science, Technology and Human Values, 31, 465-494. http://dx.doi.org/10.1177/0162243906287547

Cash, D., \& Buizer, J. (2005). Knowledge-action systems for seasonal to interannual climate forecasting: Summary of a workshop report to the Roundtable on Science and Technology for Sustainability, Policy and Global Affairs. Washington, DC: National Academy Press.

Chidzambwa, S., \& Mason, S. J. (2008). Report of the valuation of Regional Climate Outlook Forecasts for Africa during the Period 1997-2007. ACMAD Technical Report, Niamey, ACMAD.

Curran, L. M., Caniago, I., Paoli, G. D., Astianti, D., Kusneti, M., Leighton, M., ... Haeruman, H. (1999). Impact of El Niño and logging on canopy tree recruitment in Borneo. Science, 286, 2184-2188. http://dx.doi.org/10.1126/science.286.5447.2184

Dube, M. A., \& Musi, P. J. (2002). Analysis of Indigenous knowledge in Swaziland: Implications for Agricultural Development. African Technology Policy Studies Network.

Dutta, R. (2009). Information needs and information-seeking behaviour in developing countries: A review of the research. International Information and Library Review, 41, 44-51. http://dx.doi.org/10.1080/10572317.2009.10762796

Finnigan, J. (2009). The "Diabolical Problem": Reconciling Climate Mitigation and Global Change. Presentation at the CSIRO CSS Global Systems Dynamics Workshop, Lake Crackenback, NSW, Australia, June 9-12, 2009.

Flavier, J. M., Jesus, A., de Navarro, C. S., \& Warren, D. M. (1995). The regional program for the promotion of indigenous knowledge in Asia. In D. M. Warren, L. J. Slikkerveer, \& D. Brokensha (Eds.), The cultural dimension of development: Indigenous knowledge systems. London: IT Publications. http://dx.doi.org/10.3362/9781780444734.043

Friesland, H., \& Lo"pmeier, F. J. (2006). The Activities of the German Weather Service (DWD) in the Field of $\begin{array}{lllll}\text { Agroclimatology. } \quad \text { Meteorological Applications } & \text { (Supplement), } & 13, & 6167 .\end{array}$ http://dx.doi.org/10.1017/s1350482706002568

Frimpong, H. N. (2013). Indigenous knowledge and climate adaptation policy in northern Ghana, Backgrounder, 48.

Furman, C., Roncoli, C., Crane, T., \& Hoogenboom, G. (2011). Beyond the 'Fit': Introducing climate forecasts among organic farmers in Georgia (U.S.). Climatic Change, 109(3-4), 791-799. http://dx.doi.org/10.1007/s10584-011-0238-y

Gana, F. S. (2003). The Usage of Indigenous Plant Materials among Small-Scale Farmers in Niger State. Agricultural Development Project - Nigeria. Indilinga African Journal of Indigenous Knowledge Systems, 2, 
99-113.

Glantz, M. H. (2003). Climate Affairs: A Primer. Washington: Island Press.

Glantz, M. H. (2005). Usable science 9: El Niño early warning for sustainable development in Pacific Rim countries and islands. Report of workshop held September 13-16, 2004 in the Galapagos Islands, Ecuador. Boulder, ISSE/NCAR, 2005.

Goddard, L., Aitchellouche, Y., Baethgen, W., Dettinger, M., Graham, R., Hayman, P., ...Conrad, E. (2010). Providing Seasonal-to-nterannual Climate Information for Risk Management and Decision-making. Procedia Environmental Sciences, 1, 81-101. http://dx.doi.org/10.1016/j.proenv.2010.09.007

Gong, X. A., Barnston, G., \& Ward, M. N. (2003). The effect of spatial aggregation on the skill of seasonal $\begin{array}{llllll}\text { rainfall forecasts. } & \text { Journal } & \text { of } & \text { Climate, } & 16, & 30-59 .\end{array}$ http://dx.doi.org/10.1175/1520-0442(2003)016\%3C3059:TEOSAO\%3E2.0.CO;2

Gukurume, S. (2014). Climate change, variability and sustainable agriculture in Zimbabwe's rural communities. Russian Journal of Agricultural and Socio-Economic Sciences, 2(14), 89-100.

Hammer, G. L., Hansen, J., Phillips, J. G., Mjelde, J. W., Hill, H. S. J., Love, A., \& Potgieter, A. (2001). Advances in application of climate prediction in agriculture. Agricultural Systems, 70, 515-553. http://dx.doi.org/10.1016/S0308-521X(01)00058-0

Hansen, J. W. (2002). Realizing the potential benefits of climate prediction to agriculture: Issues, approaches, challenges. Agricultural Systems, 74, 309. http://dx.doi.org/10.1016/S0308-521X(02)00043-4

Hansen, J. W., Mishra, A., Rao, K. P. C., Indeje, M., \& Ngugi, R. K. (2009). Potential value of GCM-based seasonal rainfall forecasts for maize management in semi-arid Kenya. Agricultural Systems, 101, 80-90. http://dx.doi.org/10.1016/j.agsy.2009.03.005

Hinkel, K, M., Jones, B. M., Eisner, W. R., Cuomo, C. J., Beck, R. A., \& Frohn, R. (2007). Methods to assess natural and anthropogenic thaw lake drainage on the western Arctic coastal plain of northern Alaska. Journal of Geophysical Research, 112. http://dx.doi.org/10.1029/2006JF000584

Ifejika S, C. (2010). Resilient adaptation to climate change in African agriculture. Deutsches Institut für Entwicklungspolitik, 54.

Ingram, K. T., Roncoli, M. C., \& Kirshen, P. H. (2002). Opportunities and constraints for farmers of West Africa to use seasonal precipitation forecasts with Burkina Faso as a case study. Agricultural Systems, 74, 331-349. http://dx.doi.org/10.1016/S0308-521X(02)00044-6

IPCC. (2007). Climate change: Impacts, adaptation and vulnerability.Fourth Assessment Report (AR4) of the United Nations Intergovernmental Panel on Climate Change (IPCC) (Fourth Assessment Report). Cambridge: Cambridge University Press.

Jain, P. (2014). Indigenous Knowledge Management in Botswana Using ICT Applications. Concepts and Advances in Information Knowledge Management Studies from Developing and Emerging Economies (pp. 167-191). http://dx.doi.org/10.1533/9781780634357.2.167

Joshua, M. K., Ngongondo, C., Chipeta, L., \& Mpembeka, F. (2011). Integrating Indigenous Knowledge with Conventional Science: Enhancing Localised Climate and Weather Forecasts In Nessa, Mulanje, Malawi. Physics and Chemistry of the Earth, Parts A/B/C, 36(14-15), 996-1003. http://dx.doi.org/10.1016/j.pce.2011.08.001

Khanal, R. C. (2009). Climate change and organic agriculture. Journal of Agriculture and Environment, 10, 100-110. http://dx.doi.org/10.3126/aej.v10i0.2136

Kijazi A. L., Chang'a, L. B., Liwenga, E. T., Kanemba, A., \& Nindi, S. J. (2012). The use of indigenous knowledge in weather and climate prediction in Mahenge and Ismani Wards, Tanzania. Proceedings of the first Climate Change Impacts, Mitigation and Adaptation Programme Scientific Conference.

Kolawole, O. D., Wolski, P., Ngwenya, B., \& Mmopelwa, G. (2014). Ethno-meteorology and scientific weather forecasting: Small farmers and scientists' perspectives on climate variability in the Okavango Delta, Botswana. Climate Risk Management, 4-5, 43-58. http://dx.doi.org/10.1016/j.crm.2014.08.002

Laidler, G. J., \& Ikummaq T. (2008). Human geographies of sea ice: freeze/thaw processes around Igloolik, Nunavut, Canada. Polar Record, 44, 127-153. http://dx.doi.org/10.1017/s0032247407007152

Liechti, F. (2006). Birds: blowin' by the wind? Journal of Ornith, 147(2), $202-211$. 
http://dx.doi.org/10.1007/s10336-006-0061-9

Lobell, D. B., Burke, M. B., Tebaldi, C., Mastrandrea, M. D., Falcon, W. P., \& Naylor, R. L. (2008). Prioritizing climate change adaptation needs for food security in 2030. Science, 319, 607. http://dx.doi.org/10.1126/science.1152339

Luseno, W. K., McPeak, J. G., Barret, C., Little, P. D., \& Gebru, G. (2003). Assessing the value of climate forecast information for pastoralists: evidence from southern Ethiopia and northern Kenya. World Development, 31, 1477-1494. http://dx.doi.org/10.1016/S0305-750X(03)00113-X

Lybbert, T. J., Barrett, C., McPeak, J. G., \& Luseno, W. K. (2007). Bayesian herders: asymmetric updating of rainfall beliefs in response to external forecasts. World Development, 35, 480-497. http://dx.doi.org/10.1016/j.worlddev.2006.04.004

Maconachie, R. (2012). Reconciling the Mismatch: Evaluating Competing Knowledge Claims over Soil Fertility in Kano, Nigeria. Journal of Cleaner Production, 31, 62-72. http://dx.doi.org/10.1016/j.jclepro.2012.03.006

Magadza, C. H. D. (1994). Climate change: Some likely multiple impacts in Southern Africa. Food Policy, 19(2), 165-191. http://dx.doi.org/10.1016/0306-9192(94)90068-X

Makadho, J. M. (1996). Potential effects of climate change on corn production in Zimbabwe. Climate Research, 6, 147-151. http://dx.doi.org/10.3354/cr006147

Mano, R., \& Nhemachena, C. (2006). Assessment of the economic impacts of climate change on agriculture in Zimbabwe: A Ricardian approach. CEEPA Discussion Paper No. 11. Centre for Environmental Economics and Policy in Africa. Pretoria, South Africa: University of Pretoria.

Mapfumo, P., Mtambanengwe, F., \& Chikowo, R. (2015). Building on indigenous knowledge to strengthen the capacity of smallholder farming communities to adapt to climate change and variability in southern Africa. Climate and Development. http://dx.doi.org/10.1080/17565529.2014.998604

Mark, W. R., Mandy, E., Gary, Y., Lan, B., Saleemul, H., \& Rowena, V. S. (2008). Climate change and agriculture: Threats and opportunities. Federal Ministry for Economic Cooperation and Development, Germany.

Mberego, S., \& Sanga-Ngoie, K. (2012). Using locally captured climatic information for guiding local-level agriculturalists in Africa: a case study of Makonde district in Zimbabwe. Journal of Land Use Science, 9(2), 178-194. http://dx.doi.org/10.1080/1747423X.2012.758787

McIntosh, P. C., Pook, M. J., Risbey, J. S., Lisson, S. N., \& Rebbeck, M. (2007). Seasonal climate forecasts for agriculture: Towards better understanding and value. Field Crops Research, 104, 130. http://dx.doi.org/10.1016/j.fcr.2007.03.019

Memmott, P. (2010). Demand-responsive services and culturally sustainable enterprise in remote Aboriginal settings: A case study of the Myuma Group. DKCRC Report 63. Desert Knowledge Cooperative Research Centre, Alice Springs.

Moeletsi, M. E., Mellaart, E. A. R., Mpandeli, N. S., \& Hamandawana, H. (2013). The Use of Rainfall Forecasts as a Decision Guide for Small-scale Farming in Limpopo Province, South Africa. Journal of Agricultural Education and Extension, 19(2), 133-145. http://dx.doi.org/10.1080/1389224X.2012.734253

Mogotsi, K., Moroka, A. B., Sitang, O., \& Chibua, R. (2011). Seasonal precipitation forecasts: Agro-Ecological knowledge among rural Kalahari communities. African Journal of Agricultural Research, 6(4), 916-922.

Moonga, E., \& Chitambo, H. (2010). The role of Indigenous Knowledge and Biodiversity in Livestock Disease Management under Climate Change, Development in semi-arid region. Retrieved from http://africanclimate.net/en/cases/country-pilot-partnership-programme-adapting-climate-change-livestock-i ndigenous-knowledge

Muchena, P. (1994). Implication of climate change for maize yields in Zimbabwe. In C. Rosenzweig \& A. Iglesias (Eds.), Implications of climate change for international agriculture: Crop modelling study. Washington DC. US Environmental Protection Agency.

Mugabe, F. T., Mubaya, C. P., Nanja, D., Gondwe, P., Munodawafa, A., Mutswangwa, E., ... Murewi, C. (2010). Use of Indigenous Knowledge Systems and Scientific Methods for Climate Forecasting in Southern Zambia and North Western Zimbabwe. Zimbabwe Journal of Technological Sciences, 1(1), 22-36.

Muguti, T., \& Maphosa, R. (2012). Indigenous Weather Forecasting: A Phenomenological Study Engaging the 
Shona of Zimbabwe. Journal of Pan African Studies, 4(9), 102-112.

Nyong, A., Adesina, F., \& Elasha, O. B. (2007). The value of indigenous knowledge in climate change mitigation and adaptation strategies in the African Sahel. Mitigation and Adaptation Strategies in Global Change, 12, 787-797. http://dx.doi.org/10.1007/s11027-007-9099-0

Odendo, M., Ojiem, J., Bationo, A., \& Mudeheri, M. (2006). On-farm evaluation and scaling-up of soil fertility management technologies in western Kenya. Nutrient Cycling in Agroecosystems, 76, 369-381. http://dx.doi.org/10.1007/s10705-006-9060-8

Ogallo, L. (2010). The Mainstreaming of Climate Change and Variability Information into Planning and Policy Development for Africa. Procedia Environmental Sciences, $1, \quad 405-410$. http://dx.doi.org/10.1016/j.proenv.2010.09.028

Onyango, M. (2009). Kenya rainmakers called to the rescue to combat climate change. The Daily Tribune, September 22, 2009. (pp. 1-3). Retrieved March 11, 2015, from http://www.tribuneonline.org/commentary/20090922com6.html

Orlove, B. S., \& Kabugo, M. (2005). Signs and sight in southern Uganda: representing perception in ordinary conversation. Etnofoor, 23(1), 124-141.

Orlove, B., Roncoli, C., Kabugo, M., \& Majugu, A. (2010). Indigenous climate knowledge in southern Uganda: the multiple components of a dynamic regional systems. Climatic Change, 100, 243-265. http://dx.doi.org/10.1007/s10584-009-9586-2

Osbahr, H., \& Allan, C. (2003). Indigenous Knowledge of Soil Fertility Management in Southwest Niger. Geoderma, 111(3-4), 457-479. http://dx.doi.org/10.1016/S0016-7061(02)00277-X

Ouma, G. (2009). Linking traditional and modern forecasting in western Kenya. Stories from the field. Retrieved March 11, 2015, from http://idrc.org/minga/ev-148990-201-1-DO_TOPIC.html

Pasteur, K. (2011). From Vulnerability to Resilience: A framework of analysis and action to build community resilience. Practical Action Publishing. http://dx.doi.org/10.3362/9781780440583

Patt, A. G. (2001). Understanding uncertainty: forecasting seasonal climate for farmers in Zimbabwe. Risk Decision and Policy, 6, 105-119. http://dx.doi.org/10.1017/S1357530901000321

Patt, A. G., \& Gwata, C. (2002). Effective Seasonal Climate Forecast Applications: Examining Constraints for Subsistence Farmers in Zimbabwe. Global Environmental Change, 12, 185-195. http://dx.doi.org/10.1016/S0959-3780(02)00013-4

Patt, A., Suarez, P., \& Gwata, C. (2005). Effects of seasonal climate forecasts and participatory workshops among subsistence farmers in Zimbabwe. PNAS, 102, 12623-12628. http://dx.doi.org/10.1073/pnas.0506125102

Pawluk, R. R., Sandor, J. A., \& Tabor, J. A. (1992). The role of indigenous soil knowledge in agricultural development. Journal of Soil and Water Conservation, 47, 298-302.

Phillips, J., \& Orlove, B. S. (2004). Improving climate forecast communications for farm management in Uganda. Final Report to NOAA Office of Global Programs.

Phillips, J., Makaudze, E., \& Unganai, L. (2001). Current and potential use of climate forecasts for resource-poor farmers in Zimbabwe. In C. Rosenzweig (Ed.), Impacts of El Nino and Climate Variability in Agriculture (pp. 87-100). American Society of Agronomy Special Publication, Madison, Wisconsin.

Risiro, J. D., Mashoko, D., Tshuma, T., \& Rurinda, E. (2012). Weather forecasting and indigenous knowledge systems in Chimanimani district of Manicaland, Zimbabwe. Journal of Emerging Trends in Educational Research and Policy Studies, 3(4), 561-566.

Roncoli, C., Ingram, K., \& Kirshen, P. (2002). Reading the rains: Local knowledge and rainfall forecasting in Burkina Faso. Society and Nature Research, 15, 409. http://dx.doi.org/10.1080/08941920252866774

Roncoli, C., Jost, C., Kirshen, P., \& Hoogenboom, G. (2005). Risk management and social learning in farmers' responses to seasonal climate forecasts in three agro-ecological zones of Burkina Faso. Paper presented at the American Association of Geographers Annual Meeting, Denver, Colorado.

Roncoli, C., Jost, C., Kirshen, P., Sanon, M., Ingram, K. T., Woodin, M., ... Hoogenboom, G. (2009). From accessing to assessing forecasts: an end-to-end study of participatory climate forecast dissemination in Burkina Faso (West Africa). Climatic Change, 92, 433-460. http://dx.doi.org/10.1007/s10584-008-9445-6 
Roudier, P., Muller, B., d'Aquino, P., Roncoli, C., Soumaré, M. A., Batté, L., \& Sultan, B. (2014). The role of climate forecasts in smallholder agriculture: Lessons from participatory research in two communities in Senegal. Climate Risk Management, 2, 42-55. http://dx.doi.org/10.1016/j.crm.2014.02.001

Saitabau, H. (2014). Impacts of climate change on the livelihoods of loitamaasai pastoral community and related indigenous knowledge on adaptation and mitigation. Retrieved from http://africanclimate.net/en/publication s/pastoral-indigenous-knowledge-related-climate-variability-and-change-adaptation

Shoko, K., \& Shoko, N. (2013). Indigenous Weather Forecasting Systems: A Case Study of the Abiotic Weather Forecasting Indicators for Wards 12 and 13 in Mberengwa District Zimbabwe. Asian Social Science, 9(5), 285-297. http://dx.doi.org/10.5539/ass.v9n5p285

Sillitoe, P., \& Marzano, M. (2008). Failure of indigenous knowledge research in development. Futures, 41, 13-23. http://dx.doi.org/10.1016/j.futures.2008.07.004

Sivakumar, M. V. K. (2006). Climate prediction and agriculture: current status and future challenges. Climate Research, 33, 3. http://dx.doi.org/10.3354/cr033003

Stige, L. C., Stave, J., Chan, K. S., Ciannelli, L., Pretorelli, N., Glantz, M., ... Stenseth, N. C. (2006). The effect of climate variation on agro-pastoral production in Africa. PNAS, 103, 3049-3053. http://dx.doi.org/10.1073/pnas.0600057103

Suarez, P., \& Patt, A. (2004). Caution, cognition, and credibility: the risks of climate forecast application. Risk, Decision and Policy, 9, 75-89. http://dx.doi.org/10.1080/14664530490429968

Thomson, M. C., Doblas-Reyes, F. J., Mason, S. J., Hagedorn, R., Connor, S. J., Phindela, T., ... Palmer, T. N. (2006). Malaria early warnings based on seasonal climate forecasts from multi-model ensembles. Nature, 439-576. http://dx.doi.org/10.1038/nature04503

UNEP. (2008). Indigenous Knowledge in Disaster Management in Africa. Retrieved from http://africanclimate.net/sites/default/files/Indigenous\%20Booklet\%20UNEP.PDF.

Vijfhuizen, C. (1997). Rain-making, political conflicts and gender images: a case from Mutema chieftaincy in Zimbabwe. Zambezia, xxiv(i), 31-49.

WFP (World Food Programme). (2006). World Hunger Series 2006: Hunger and learning. Retrieved from http://www.unicef.org/lac/World_Hunger_Series_2006_Full.pdf.

Zillman, J. (2009). Adaptation to a variable and changing climate: Challenges and opportunities for NMHSs. Scientific Lecture, World Meteorological Organisation, EC-LXI, Geneva, June 11, 2009.

Zuma-Netshiukhwi, G., Stigter, K., \& Walker, S. (2013). Use of Traditional Weather/Climate Knowledge by Farmers in South-Western Free State of South Africa: Agrometeorological Learning by Scientists. Atmosphere, 4, 383-410. http://dx.doi.org/10.3390/atmos4040383

\section{Copyrights}

Copyright for this article is retained by the author(s), with first publication rights granted to the journal.

This is an open-access article distributed under the terms and conditions of the Creative Commons Attribution license (http://creativecommons.org/licenses/by/3.0/). 